\title{
Diet selection priorities in growing pigs offered a choice of feeds
}

\author{
N.S. Ferguson ${ }^{1 \#}$, M.M.V. Bradford ${ }^{2}$ and R.M. Gous ${ }^{1}$ \\ ${ }^{1}$ School of Agricultural Sciences and Agribusiness, University of Natal, P Bag X 01, Scottsville 3209, South Africa \\ ${ }^{2}$ Meadow Feeds (Natal), P O Box 426, Pietermaritzburg 3200, South Africa
}

\begin{abstract}
Two experiments were conducted to test whether young pigs are capable of discriminating against a feed based on its nutrient balance (or protein value) and/or the presence or absence of anti-nutritional factors, and whether there is an order of preference. In each experiment 48 Large White $\mathrm{x}$ Landrace female pigs weighing $16.5 \pm 1.50 \mathrm{~kg}$ were randomly allocated to one of either 12 dietary treatments (Experiment 1 ) or 14 dietary treatments (Experiment 2) and kept on the treatment diets for four weeks. In Experiment 1 there were four single feed control treatments, four two-feed choice treatments and four three-feed treatments. The choices were between soyabean oilcake $v s$. cottonseed oilcake as the main dietary protein source, and between diets that have a higher (balanced) versus lower (unbalanced) proportion of amino acids compared with the balance of amino acids in ideal protein. Experiment 2 had similar choices to Experiment 1, but also included treatments with $1 \%$ added tannin. The results showed that when young pigs were given a choice of diets their preference was firstly against potentially harmful substances in the feed (e.g. tannin) or an anti-nutritive factor (e.g. cottonseed oilcake), and then for better-balanced or higher protein-value feeds.
\end{abstract}

Keywords: Food preferences, pigs, palatability, growth

${ }^{*}$ Corresponding author. E-mail: ferguson@nu.ac.za

\section{Introduction}

Predicting the voluntary food intake of animals is complex. But because of its importance in the design of optimum economic feeds and feeding schedules for animals, many attempts have been made to produce a set of rules that may successfully be applied to solve the problem. One of the most successful theories for predicting voluntary food intake is that of Emmans (1981) and Emmans \& Fisher (1986). The central principle in this theory is that an animal will eat to satisfy its requirement for the first limiting nutrient in the feed, as a means of growing at its potential, if it is possible to consume that amount of feed, given the constraints of feed bulk and environmental temperature. A corollary to this theory is that if an animal is faced with two or more feeds, differing in nutrient content, the animal will be able to find one feed, or a combination of the feeds, that will satisfy its requirement for growth or production, provided that such a feed or a combination of feeds exists in the choice offered. A choice feeding trial is therefore a useful method of determining some of the rules used by animals when deciding how much, and what, to eat (Bradford \& Gous, 1992). For a more comprehensive review of choice feeding and feeding behaviour in pigs refer to Kyriazakis (1994) and Kyriazakis (1997).

There is a good deal of evidence to suggest that pigs have the ability to select, from two foods, (1) a combination that closely matches their protein requirement (Bradford \& Gous, 1991; Kyriazakis \& Emmans, 1993); (2) on the basis of nutrient density (Ferguson et al. 1999); and (3) on the basis of anti-nutritional factors or unpalatable components within the feed (e.g. gossypol) (Bradford \& Gous, 1992; Kyriazakis \& Emmans, 1993). However, there is limited data on dietary preferences between feeds differing in amino acid balance and various combinations of the above mentioned selection criteria. Of particular interest are the choices made between feeds differing in amino acid balance and those feeds in which anti-nutritional factors are either present or absent. By measuring their preferences when offered three-way choices it is possible to determine the priorities used by pigs when deciding upon the amount and the composition of the feed to consume each day, and on what basis a feed should be avoided, thereby improving our understanding of the factors influencing voluntary food intake in pigs.

The objectives of this paper were to investigate whether pigs are capable of discriminating against a feed based on its biological value (ratio of essential amino acids), the presence or absence of a feed ingredient that pigs are known to dislike (cottonseed oilcake) (Bradford \& Gous, 1992) and/or the presence or absence of tannin in the diet, as well as the order of preference. 


\section{Materials and methods}

Two experiments are reported here. In both experiments, 48 commercial Large White $\mathrm{x}$ Landrace piglets, with an initial live weight of $16.5 \pm 1.05 \mathrm{~kg}$, were grown for four weeks. Each animal was housed individually in pens measuring $0.96 \mathrm{~m} \times 2.20 \mathrm{~m}$ in size and supplied with three feeders and a single nipple drinker. Pigs were weighed on a weekly basis. All feeds were supplied ad libitum and food intake was recorded weekly by weighing back the remaining food and subtracting it from the amount of food allocated.

Before each experiment began, each pig was subjected to an initial training period during which time they were given the opportunity to learn the position and physical attributes of the diets to be fed once the trial began. During this training period, which lasted three days, the pigs were offered a single feed for half of each day, the feeds being alternated on a twice-daily basis.

Twelve dietary treatments were used in Experiment 1 (Table 1) with each treatment being replicated four times. Four control treatments were included, in which the basal feeds were fed alone. Four choice treatments were used in which two of the basal feeds were offered simultaneously, and in the remaining four treatments, three of the control feeds were offered simultaneously.

Table 1 A description of the feed treatments used in Experiment 1

\begin{tabular}{cl}
\hline Treatment & \multicolumn{1}{c}{ Description } \\
\hline 1 & Cottonseed Unbalanced (Cot U) \\
2 & Cottonseed Balanced (Cot B) \\
3 & Soybean Unbalanced (Soy U) \\
4 & Soybean Balanced (Soy B) \\
5 & Cot B vs. Cot U \\
6 & Soy B vs. Soy U \\
7 & Cot B vs. Soy B \\
8 & Cot U vs. Soy U \\
9 & Cot B vs. Soy U vs. Soy B \\
10 & Cot B vs. Cot U vs. Soy B \\
11 & Cot U vs. Soy B vs. Soy U \\
12 & Cot U vs. Cot B vs. Soy U \\
\hline
\end{tabular}

In the second experiment there were 14 treatments each replicated three times (Table 2). In this case, six control treatments were included, in which the basal feeds, excluding the Soy U treatment, were fed alone or with the addition of tannin, at a concentration of $10 \mathrm{~g} / \mathrm{kg}$ of feed. As there were only 48 pens it was not possible to do all combinations of treatments and therefore the Soy U and Soy UT treatments were excluded. The reason for exclusion was to satisfy one of the objectives of the experiment, which was to consider whether animals would prefer to select on the basis of nutrient balance or anti-nutritional factors and therefore it was more important to include treatments with cottonseed oilcake as the main protein source. Eight choice treatments were included, of which five had two feeds offered simultaneously, and the remaining three had three of the control feeds offered simultaneously (Table 2). In both experiments the treatments were imposed using a completely random design.

The basal feeds were common to both experiments and were formulated using either cottonseed oilcake or soyabean oilcake as the predominant source of dietary protein. The diets were designed to be either balanced or unbalanced with respect to the amino acid balance of ideal protein (Whittemore, 1997). This was achieved by either including or excluding the synthetic form of the most limiting amino acid in each basal diet (DLmethionine in the case of soybean oilcake, and $\mathrm{L}-$ lysine $\mathrm{HCl}$ in the cottonseed oilcake). Table 3 is a summary of the calculated and analysed chemical composition of the basal diets.

Balanced diets contained a higher proportion of the most limiting amino acid relative to the amount of ideal protein required and, therefore, they had a higher biological or protein value. Unbalanced diets, on the other hand, had a lower proportion of the most limiting amino acid and hence a lower protein value. The protein value of the Soy B basal diet was 0.85 and was determined by the limiting concentration of methionine, whereas for the Cot B basal diet, dietary lysine limited the value to 0.70 . For the unbalanced basal diets the protein values were 0.70 and 0.49 for soyabean- and cottonseed-based diets, respectively. Free gossypol concentration of the cottonseed based diets was calculated to be $53 \mathrm{mg} / \mathrm{kg}$ (Smith, 1968). 
Table 2 A description of the feed treatments used in Experiment 2

\begin{aligned} & \hline Treatment \multicolumn{1}{c}{ Description } \\ & \hline 1 Cottonseed Unbalanced (Cot U) \\ & 2 Cottonseed Balanced (Cot B) \\ & 3 Cot U + Tannin (Cot UT) \\ & 4 Cot B + Tannin (Cot BT) \\ & 5 Soybean Balanced (Soy B) \\ & 6 Soy B + Tannin (Soy BT) \\ & 7 Cot U vs. Cot B \\ & 8 Cot U vs. Cot UT \\ & 9 Cot B vs. Cot BT \\ & 10 Cot B vs. Soy BT \\ & 11 Cot B vs. Soy B \\ & 12 Cot BT vs. Cot B vs. Soy BT \\ & 13 Cot BT vs. Cot UT vs. Soy BT \\ & 14 Cot B vs. Soy B vs. Cot U \\ & \hline\end{aligned}

Table 3 Ingredient and nutrient composition of the basal feeds used in the two experiments (as fed basis)

\begin{tabular}{|c|c|c|c|c|}
\hline & $\begin{array}{c}\text { Soya } \\
\text { Balanced* }\end{array}$ & $\begin{array}{c}\text { Cotton } \\
\text { Balanced }\end{array}$ & $\begin{array}{c}\text { Soya } \\
\text { Unbalanced } \dagger\end{array}$ & $\begin{array}{c}\text { Cotton } \\
\text { Unbalanced }\end{array}$ \\
\hline \multicolumn{5}{|l|}{ Ingredient (g/kg) } \\
\hline Yellow maize & 735.8 & 629.4 & 735.8 & 629.4 \\
\hline Soybean oilcake & 222.6 & - & 222.6 & - \\
\hline Cottonseed oilcake & - & 264.8 & - & 264.8 \\
\hline Maize gluten 60 & - & 50.0 & - & 50.0 \\
\hline Monocalcium phos. & 12.1 & 6.8 & 12.1 & 6.8 \\
\hline Limestone & 20.2 & 19.6 & 20.2 & 19.6 \\
\hline Salt & 3.2 & 3.2 & 3.2 & 3.2 \\
\hline Vit \& Min premix & 2.5 & 2.5 & 2.5 & 2.5 \\
\hline Lysine- $\mathrm{HCl}$ & 3.1 & 4.1 & 3.1 & - \\
\hline DL-methionine & 0.50 & 0.02 & - & 0.02 \\
\hline Sunflower oil & - & 19.6 & - & 19.6 \\
\hline \multicolumn{5}{|c|}{ Nutrients analysed (g/kg) } \\
\hline DE (Pig) (MJ/kg) & 14.15 & 14.25 & 14.11 & 14.05 \\
\hline Crude protein & 154.8 & 188.2 & 147.0 & 188.9 \\
\hline Lysine & 10.08 & 9.21 & 9.82 & 6.47 \\
\hline Methionine & 2.64 & 2.94 & 2.11 & 2.88 \\
\hline Calcium & 12.12 & 9.10 & 11.40 & 9.80 \\
\hline Phosphorus & 6.20 & 6.60 & 5.60 & 6.50 \\
\hline Protein value & 0.85 & 0.70 & 0.70 & 0.49 \\
\hline
\end{tabular}

* Balanced refers to a higher proportion of dietary amino acids compared with the balance of amino acids in ideal protein.

$\dagger$ Unbalanced refers to a lower proportion of dietary amino acids compared with the balance of amino acids in ideal protein.

$\$$ Protein value is lowest score between lysine and methionine calculated from the function:

( $\mathrm{g}$ amino $\mathrm{acid} / \mathrm{kg}$ protein in feed) / ( $\mathrm{g}$ amino acid/kg ideal protein)

where $\mathrm{g} / \mathrm{kg}$ ideal protein are 70 and 20, for lysine and methionine, respectively (Whittemore, 1997).

ๆ DE (Digestible energy) $=3.77$ - (0.19 x NDF $)+(0.75 \times$ GE) (Whittemore, 1997)

All statistical analyses were performed using Minitab version 10 for Windows (State College, Pennsylvania, USA). The main effects of the single and choice-fed treatments were analysed using the ANOVA procedure. Where specific comparisons between treatments were made, a Student's $t$ test was performed. Linear regression analyses were used to determine weekly differences in the proportions of diets consumed relative to total food intake. 


\section{Results}

The results in Experiment 1 for average daily gain (ADG), food intake (FI) and food conversion efficiency ( $\mathrm{g}$ gain $/ \mathrm{kg}$ food) (FCE) in Experiment 1 are presented in Table 4.

Table 4. Average daily gain (ADG), food intake (as fed basis) and food conversion efficiency (FCE) of pigs on single feeds, or on the choice-feeding treatments in Experiment 1.

\begin{tabular}{llccc}
\hline Treatment Description & $\begin{array}{c}\text { ADG } \\
(\mathrm{g} / \mathrm{pig} / \mathrm{d})\end{array}$ & $\begin{array}{c}\text { Food Intake } \\
(\mathrm{g} / \mathrm{pig} / \mathrm{d})\end{array}$ & $\begin{array}{c}\text { FCE } \\
\text { (g gain/kg feed) }\end{array}$ \\
\hline 1 & Cottonseed Unbalanced* (Cot U) & 320.5 & 1030.5 & 312.1 \\
2 & Cotton Balanced $\dagger$ (Cot B) & 748.2 & 2008.7 & 378.6 \\
3 & Soya Unbalanced (Soy U) & 789.3 & 1857.5 & 425.7 \\
4 & Soya Balanced (Soy B) & 784.8 & 1625.2 & 505.7 \\
5 & Cot B $v$ s. Cot U & 640.2 & 1532.3 & 415.2 \\
6 & Soy B vs. Soy U & 772.3 & 1698.9 & 454.2 \\
7 & Cot B $v$ s. Soy B & 806.3 & 1976.6 & 412.0 \\
8 & Cot U vs. Soy U & 789.3 & 1631.8 & 482.7 \\
9 & Cot B $v$. Soy U vs. Soy B & 782.2 & 1733.4 & 450.7 \\
10 & Cot B vs. Cot U vs. Soy B & 813.4 & 1711.6 & 480.8 \\
11 & Cot U vs. Soy B vs. Soy U & 790.2 & 1835.2 & 438.6 \\
12 & Cot U vs. Cot B vs. Soy U & 745.6 & 1695.2 & 448.6 \\
& & & & \\
& LSD & 156.5 & 431.7 & 110.4 \\
& s.e.d. & 63.96 & 176.40 & 45.10 \\
\hline
\end{tabular}

* Unbalanced refers to a lower proportion of dietary amino acids compared with the balance of amino acids in ideal protein.

$\dagger$ Balanced refers to a higher proportion of dietary amino acids compared with the balance of amino acids in ideal protein. LSD $=$ Least significant differences

There were significant differences in growth rate between treatments, with the lowest ADG recorded in pigs on Treatment 1 (unbalanced cottonseed basal diet) $(0.321 \pm 0.059 \mathrm{~kg} / \mathrm{d})$ and the highest on Treatment 10 $(0.813 \pm 0.027 \mathrm{~kg} / \mathrm{d})$. Treatments that contained only cottonseed-based diets (T1, T2 and T5) had noticeably lower ADG than treatments that contained at least one soyabean-based diet. However, ADG on T2 was not significantly lower than on the remaining treatments. Total food intake was found to be significantly different between treatments but with no consistent trend. The efficiency of converting food to body weight followed a similar trend to ADG where significant $(\mathrm{P}=0.014)$ differences between treatments were observed. The highest FCE (506 $\pm 56.9 \mathrm{~g}$ gain $/ \mathrm{kg}$ feed) was reported in pigs on T4 (single feed, balanced Soyabean-based diet) and the lowest on T1 and T2 (single feed, Cottonseed-based diets) of $312 \pm 19.7$ and $378 \pm 30.8 \mathrm{~g}$ gain $/ \mathrm{kg}$ feed, respectively.

The preferences and amounts of feed consumed as a proportion of total feed intake when pigs were offered a single feed or a choice between two or three feeds are shown in Table 5.

In Experiment 1 there were no significant preferences or changes in preference over time for Treatments 1 and 3. There was an initial preference for one bin in Treatments 2 and 4, but this preference changed over time. Of the treatments that were offered a choice between two feeds (e.g. T5 to T8) there was a significant preference for diets with soyabean oilcake, irrespective of the amino acid balance. In Treatment 5, where the choice was between balanced and unbalanced cottonseed, there was a significant preference for the balanced feed. Where there was a three way choice (T9-T12), all treatments showed a similar response with a significant preference for soyabean oilcake as the main dietary protein source.

The results for ADG, FI and FCE in Experiment 2 are presented in Table 6. There were significant differences in growth rates between treatments with the highest rates occurring in treatments containing the balanced soyabean diet without tannin (Soy B). Animals on T5 (single balanced soyabean) grew the fastest at $868 \pm 12.53 \mathrm{~g} / \mathrm{d}$. The slowest growing animals were those fed diets containing unbalanced cottonseed Oilcake with or without tannin, with the lowest ADG $(313 \pm 21.5 \mathrm{~g} / \mathrm{d})$ occurring in pigs on T3 (single unbalanced cottonseed plus tannin). Although there were large differences in total feed intakes between treatments, these were not significant. There were significant differences in FCE with similar trends as reported for ADG. Pigs 
on treatments containing cottonseed oilcake had the lowest FCE (T3 $258 \pm 4.8 \mathrm{~g}$ gain $/ \mathrm{kg}$ feed; T7 $265 \pm 41.3 \mathrm{~g}$ gain/ $\mathrm{kg}$ feed), irrespective of whether it was balanced or not, or whether the diet included or excluded tannin.

Table 5 Preferences and proportions (\%) of feed (indicated in bold) consumed relative to total feed intake over time, when pigs were offered a choice between two or three feeds in Experiment 1

\begin{tabular}{|c|c|c|c|c|c|c|c|}
\hline & & \multicolumn{4}{|c|}{ Week } & \multicolumn{2}{|c|}{ Preference } \\
\hline \multicolumn{2}{|c|}{ Treatment Comparisons } & 1 & 2 & 3 & 4 & $\begin{array}{l}\text { For feed } \\
\text { (in bold) }\end{array}$ & $\begin{array}{l}\text { Changes } \\
\text { over time }\end{array}$ \\
\hline 1 & $\operatorname{Cot} \mathbf{U}^{*} v s . \operatorname{Cot} \mathrm{U}$ & 44 & 52 & 33 & 40 & No & No \\
\hline 2 & $\operatorname{Cot} \mathbf{B} \uparrow v s . \operatorname{Cot} \mathrm{B}$ & 62 & 52 & 48 & 27 & Yes & Yes \\
\hline 3 & Soy $\mathbf{U} v s$. Soy U & 42 & 71 & 47 & 30 & No & No \\
\hline 4 & Soy B vs. Soy B & 74 & 68 & 50 & 32 & Yes & Yes \\
\hline 5 & $\operatorname{Cot} \mathbf{B} v s$. Cot $\mathrm{U}$ & 89 & 90 & 90 & 75 & Yes & No \\
\hline 6 & Soy B vs. Soy U & 55 & 46 & 54 & 54 & No & No \\
\hline 7 & Cot B vs. Soy B & 81 & 84 & 93 & 90 & Yes & No \\
\hline 8 & Cot U vs. Soy U & 87 & 97 & 99 & 97 & Yes & No \\
\hline 9 & Cot B vs. Soy U vs. Soy B & 69 & 74 & 79 & 71 & Yes & No \\
\hline 10 & Cot B vs. Cot Uvs. Soy B & 84 & 89 & 83 & 56 & Yes & No \\
\hline 11 & Cot U vs. Soy B vs. Soy U & 53 & 62 & 72 & 61 & Yes & No \\
\hline 12 & Cot U vs. Soy B vs. Soy U & 90 & 94 & 91 & 77 & Yes & No \\
\hline
\end{tabular}

* Unbalanced refers to a lower proportion of dietary amino acids compared with the balance of amino acids in ideal protein.

$\uparrow$ Balanced refers to a higher proportion of dietary amino acids compared with the balance of amino acids in ideal protein. $\S$ Preference for feed (in bold) relative to the null hypothesis: "Yes" for two feeds if proportion significantly > 50\%; "Yes" for three feeds if proportion significantly $>33 \%$

I Preference changes over time: "Yes" if linear coefficient is significantly $(\mathrm{P}<0.05)$ different from zero.

Table 6 Average daily gain (ADG), food intake (as fed basis) and food conversion efficiency (FCE) of pigs on single feeds or on the choice-feeding treatments in Experiment 2

\begin{tabular}{llccc}
\hline Treatments & $\begin{array}{c}\text { ADG } \\
(\mathrm{g} / \mathrm{p} \text { ig/d) }\end{array}$ & $\begin{array}{c}\text { Food Intake } \\
(\mathrm{g} / \mathrm{pig} / \mathrm{d})\end{array}$ & $\begin{array}{c}\text { FCE } \\
\text { (g gain/kg feed) }\end{array}$ \\
\hline 1 & Cotton Unbalanced* (Cot U) & 491.6 & 1554.1 & 308.7 \\
2 & Cotton Balanced† (Cot B) & 692.8 & 2129.3 & 324.6 \\
3 & Cot U + Tannin (Cot UT) & 313.1 & 1214.1 & 257.9 \\
4 & Cotton B + Tannin (Cot BT) & 550.0 & 1817.6 & 303.3 \\
5 & Soybean B (Soy B) & 867.9 & 2104.3 & 412.4 \\
6 & Soy B + Tannin (Soy BT) & 820.2 & 2143.3 & 392.0 \\
7 & Cot U vs. Cot B & 472.6 & 1897.6 & 265.4 \\
8 & Cot U vs. Cot UT & 372.6 & 1314.6 & 282.9 \\
9 & Cot B $v s$. Cot BT & 678.6 & 1980.7 & 342.2 \\
10 & Cot B $v s$. Soy BT & 790.5 & 1979.2 & 399.3 \\
11 & Cot B $v s$. Soy B & 810.7 & 1980.0 & 409.0 \\
12 & Cot B T vs. Cot B $v s$. Soy BT & 795.2 & 1983.6 & 400.7 \\
13 & Cot B T $v s$. Cot UT vs. Soy BT & 611.9 & 1637.1 & 367.6 \\
14 & Cot B $v s$. Soy B vs. Cot U & 832.1 & 2036.2 & 408.3 \\
& & & & 63.6 \\
& LSD & 231.3 & 721.8 & 26.00 \\
\hline
\end{tabular}

* Unbalanced refers to a lower proportion of dietary amino acids compared with the balance of amino acids in ideal protein.

$\dagger$ Balanced refers to a higher proportion of dietary amino acids compared with the balance of amino acids in ideal protein. LSD $=$ Least significant differences.

Food intakes on each treatment, expressed as a proportion eaten of one of the feeds offered in each choice, and the change in preferences over time are shown in Table 7. 
Of the six treatments, where only a single basal feed was offered in both bins (T1-T6), only T4 suggested that pigs had a non-changing preference for a feed, based on the position of the feeding trough. Given a choice of two different feeds that differed only in the inclusion of tannin (T8 and T9), pigs had a significant preference against tannin. However, in the case of T9, this aversion against tannin declined with time. Treatments where there was a three way choice $(\mathrm{T} 12-\mathrm{T} 14)$ showed that pigs had a clear preference $(\mathrm{P}<0.05)$ for soyabean-based diets even if it contained one percent tannin.

Table 7 Preferences and proportions (\%) of feed (indicated in bold) consumed relative to total feed intake over time, when pigs were offered a choice between two or three feeds in Experiment 2

\begin{tabular}{|c|c|c|c|c|c|c|c|}
\hline \multirow{2}{*}{\multicolumn{2}{|c|}{ Treatment Comparisons }} & \multicolumn{4}{|c|}{ Week } & \multicolumn{2}{|c|}{ Preference } \\
\hline & & \multirow{2}{*}{$\frac{1}{66}$} & \multirow{2}{*}{$\frac{2}{38}$} & \multirow{2}{*}{$\frac{3}{43}$} & \multirow{2}{*}{$\frac{4}{64}$} & \multirow{2}{*}{$\begin{array}{c}\begin{array}{c}\text { For feed } \S \\
\text { (in bold) }\end{array} \\
\text { No }\end{array}$} & \multirow{2}{*}{$\begin{array}{c}\begin{array}{c}\text { Changes } \Phi \\
\text { Over time }\end{array} \\
\text { No }\end{array}$} \\
\hline 1 & $\operatorname{Cot} \mathbf{U}^{*} v s . \operatorname{Cot} \mathrm{U}$ & & & & & & \\
\hline 2 & Cot UT** vs. Cot UT & 43 & 36 & 46 & 24 & No & No \\
\hline 3 & $\mathbf{C o t} \mathbf{B} \uparrow v s . \operatorname{Cot} \mathbf{B}$ & 80 & 74 & 57 & 30 & Yes & Yes \\
\hline 4 & Cot BT vs. Cot BT & 89 & 87 & 64 & 66 & Yes & No \\
\hline 5 & Soy B $v s$. Soy B & 74 & 72 & 47 & 60 & No & No \\
\hline 6 & Soy BT $v s$. Soy BT & 56 & 51 & 75 & 50 & No & No \\
\hline 7 & Cot U vs. Cot B & 35 & 67 & 54 & 62 & No & No \\
\hline 8 & $\operatorname{Cot} \mathbf{U} v s . \operatorname{Cot} \mathrm{UT}$ & 70 & 70 & 68 & 76 & Yes & No \\
\hline 9 & Cot B vs. Cot BT & 80 & 71 & 49 & 34 & Yes & Yes \\
\hline 10 & Cot B vs. Soy BT & 34 & 54 & 68 & 90 & No & Yes \\
\hline 11 & Cot B vs. Soy B & 96 & 72 & 60 & 49 & Yes & Yes \\
\hline 12 & Cot BT vs. Cot B vs. Soy BT & 59 & 62 & 53 & 38 & Yes & No \\
\hline 13 & Cot BT vs. Cot UT vs. Soy BT & 59 & 67 & 56 & 33 & Yes & No \\
\hline 14 & Cot B vs. Soy B vs. Cot U & 79 & 85 & 93 & 74 & Yes & No \\
\hline
\end{tabular}

* Unbalanced refers to a lower proportion of dietary amino acids compared with the balance of amino acids in ideal protein. ** Inclusion of $10 \mathrm{~g} / \mathrm{kg}$ tannin in diet

$\dagger$ Balanced refers to a higher proportion of dietary amino acids compared with the balance of amino acids in ideal protein. $\S$ Preference for feed (in bold) relative to the null hypothesis: "Yes" for two feeds if proportion significantly $>50 \%$; "Yes" for three feeds if proportion significantly $>33 \%$

ๆ Preference changes over time: "Yes" if linear coefficient is significantly $(\mathrm{P}<0.05)$ different from zero.

\section{Discussion}

The null hypothesis in choice feeding studies is that an equal amount of food will be chosen from each trough and, therefore, there is no positional effect of the trough on the choice made by the pig. In the two experiments reported in this paper, no positional preference was noted in pigs given a choice of feeds. This was shown in Treatments 1 and 3 (Experiment 1) and Treatments 1, 2, 5 and 6 (Experiment 2) where the same food was offered in each trough and the proportion of FI did not differ significantly from 0.5 for each trough (Tables 5 and 7). Even where there was an initial preference for a trough in Treatments 2 and 4 (Experiment 1) and T 3 (Experiment 2) this changed over time. These results confirm those of Ferguson et al. (1999), showing that the position of the feed is not a selection criterion used by pigs when they are given a choice of identical feeds.

From the ADG and FCE results given in Tables 4 and 6, pigs offered a single balanced feed (Experiment 1: T2 and T4; Experiment 2: T2, T4, T5 and T6) performed better than those on a single unbalanced feed (Experiment 1: T1 and T3; Experiment 2: T1 and T3). A comparison between treatments in which diets with a similar protein value were offered (Balanced Cottonseed, T2 vs. Unbalanced Soyabean, T3) showed no significant differences in growth, food intake or FCE, suggesting that pigs were constrained by the first limiting amino acid (lysine in T2 and methionine in T3). If performance is constrained by an amino acid, then increasing the concentration of the limiting amino acid should at least maintain growth and decrease food intake and thereby improve FCE. This pattern occurred in Experiment 1 where increasing the protein value, which is essentially the same as increasing the dietary content of the first limiting amino acid, caused a reduction in feed intake and a reduction in FCE (compare T3 vs. T4). The converse of this theory implies that reducing the protein value or making one amino acid even more limiting compared with the balance of amino acids in ideal protein, should reduce performance. Evidence for this theory was shown in both Experiments 1 and 2 where significant reductions $(\mathrm{P}<0.05)$ in ADG and FI were recorded between $\mathrm{T} 2$ (protein value $=0.70$ ) and $\mathrm{T} 1$ 
(protein value $=0.49$ ). Indications are that when given a choice between a balanced diet over an unbalanced diet growing pigs will favour the balanced diet (Experiment 1: T5 and Experiment 2: T7).

The results from both experiments strongly suggest that young pigs prefer feeds based on soyabean oilcake as the primary dietary protein source, rather than feeds based on cottonseed oilcake (Experiment 1: Treatments 7 and 8; Experiment 2: T11). This was confirmed by the responses in pigs when they were given a three-way choice between a balanced diet and an unbalanced diet, and had to make a choice between feeds based on soyabean oilcake or cottonseed oilcake. In this case they selected the balanced diet based on soyabean oilcake (Experiment 1: T9-T11; Experiment 2: T12-T14). Even when offered a choice between a balanced diet based on cottonseed and an unbalanced soyabean-based diet, with similar protein values (Experiment 1: T12), pigs preferred the soyabean diet, suggesting that their strategy is first to avoid diets that are less 'palatable' or contain anti-nutritional factors (dislike for cottonseed oilcake) and then to choose feeds that have a favourable amino acid balance. Bradford \& Gous (1992) found a similar preference for soyabean-based diets in pigs given a choice between diets based on soyabean oilcake and other plant protein oilcakes (which included cottonseed oilcake). Although the estimated concentration of gossypol $(53 \mathrm{mg} / \mathrm{kg})$ in the cottonseed based diets is below the toxic level of $100 \mathrm{mg} / \mathrm{kg}$ in growing pigs (Aherne \& Kennelly, 1985), the persistent dislike for cottonseed oilcake may be attributable to the presence of gossypol or else to some other unknown palatability factor in cotton seeds. Kyriazakis \& Emmans $(1992 ; 1993)$ observed a strong avoidance pattern against foods that contained toxins (glucosinolates) in pigs given a choice between diets. Their evidence would suggest that pigs can discriminate against potentially harmful substances in the feed. The results of the experiments in this paper are consistent with this theory.

To test this hypothesis further, some of the diets in Experiment 2 contained an anti-nutritional factor (tannin). Results from Table 6 show that when tannin was added to the basal diets at a rate of $10 \mathrm{~g} / \mathrm{kg}, \mathrm{ADG}, \mathrm{FI}$ and FCE were all lowered (T1 and T3 vs. T2 and T4; T5 vs. T6) (Table 6). This confirmed that tannin does have a negative physiological response in growing pigs. Pigs given the choice of two feeds that differed only in the amount of tannin inclusion (Experiment 2: T8, T9 and T10) chose the feed that did not contain tannin, although this preference declined as the trial progressed in time. This aversion to tannin was not as great as that toward cottonseed oilcake, as noted by the results from T12 in Experiment 1, where the pigs preferred (P $<$ 0.05 ) the unbalanced soyabean-based diet with tannin to the balanced cottonseed-based diet without tannin.

Based on the results obtained in this trial it can be concluded that young pigs, given a choice of diets, will base the selection of the feed to be consumed, firstly, on the presence or absence of a potentially harmful substance in the feed (e.g. tannin) or an anti-nutritive factor (e.g. cottonseed oilcake), and secondly, on the nutrient balance or protein value of the diet. These are important findings and impact significantly on the theory applied in the prediction of food intake.

\section{Ackowledgements}

The authors wish to thank D. Davies, M. Ferreira and M. Hundley for their technical assistance. This work was supported by grants from the Protein Research Trust.

\section{References}

Aherne, F.X. \& Kennelly, J.J., 1985. Oilseed meals for livestock feeding. In: Recent developments in pig nutrition. Eds. Cole, D.J.A. \& Haresign, W., Butterworths, London. pp. 278-315.

Bradford, M.M.V. \& Gous, R.M., 1991. The response of growing pigs to a choice of diets differing in protein content. Anim. Prod. 52, 185-192.

Bradford, M.M.V. \& Gous, R.M., 1992. The response of weaner pigs to a choice of diets differing in protein content. Anim. Prod. 55, 227-232.

Emmans, G.C., 1981. A model of the growth and feed intake of ad libitum fed animals, particularly poultry. In: Computers in Animal Production. Occ. Publ. No. 5. Brit. Soc. Anim. Prod. Eds. Hillyer, C.T., Whittemore, C.T., \& Gunn, R.G. Edinburgh. pp. 103-110.

Emmans, G.C. \& Fisher, C., 1986. Problems in nutritional theory. In: Nutrient Requirements of Poultry and Nutritional Research. Eds. Fisher, C \& Boorman, K.N., Butterworths, London. pp. 9-39.

Ferguson, N.S., Nelson, L. \& Gous, R.M., 1999. Diet selection in pigs: choices made by growing pigs when given foods differing in nutrient density. Anim. Sci. 68, 691-699.

Kyriazakis, I., 1994. The voluntary food intake and diet selection of pigs. In: Principles of Pigs Science. Eds.

Wiseman, J., Cole, D.J.A. \& Varley, M.A., Nottingham University Press, Nottingham. pp. 86-105. 
Kyriazakis, I., 1997. The nutritional choices of farm animals: to eat or what to eat ? In: Animal Choice. Occ. Publ. No. 20. Brit. Soc. Anim. Sci.. Eds. Forbes, J.M., Lawrence, T.L.J., Rodway, R.G. \& Varley, M.A., Edinburgh. pp. 55-65.

Kyriazakis, I. \& Emmans, G.C., 1992. The selection of a diet by growing pigs given choices between feeds differing in their contents of protein and rapeseed meal. Appetite 19, 121-132.

Kyriazakis, I. \& Emmans, G.C., 1993. The effect of protein source on the diets selected by pigs given a choice between a low and high protein food. Physiol. Behav. 53, 683-688.

Smith, F.H., 1968. Estimation of free gossypol in cottonseed meal and cottonseed meats: modified method. J. Amer. Oil Chem. Soc. 45, 903.

Whittemore, C.T., 1997. The Science and Practice of Pig Production ( $2^{\text {nd }}$ ed.). Longman Scientific \& Technical, Essex. 